\title{
A Late Holocene pollen and microcharcoal record from Eilandvlei, southern Cape coast, South Africa
}

\author{
Nadia du Plessis
}

Department of Environmental and Geographical Science, University of Cape Town, Rondebosch, South Africa

Brian M. Chase ${ }^{1}$

Institut des Sciences de l'Evolution-Montpellier (ISEM), University of Montpellier, Centre National de la Recherche Scientifique (CNRS), EPHE, IRD, Montpellier, France

Lynne J. Quick

African Centre for Coastal Palaeoscience, Nelson Mandela University, Port Elizabeth, South Africa

Michael E. Meadows ${ }^{2}$

Department of Environmental and Geographical Science, University of Cape Town, Rondebosch, South Africa

\subsection{SITE DETAILS}

Eilandvlei forms part of the Wilderness Lakes system located along the southern Cape coast of South Africa (Figure 1A, B). These lakes are located behind Pleistocene dune ridges that run parallel along the coastline. Situated within South Africa's aseasonal rainfall zone, climate is influenced by both temperate and tropical circulation systems.

The regional vegetation (Figure 1B, C) is most noteworthy for the extensive development of Southern Afrotemperate Forest (generally Afrocarpus falcatus, Podocarpus latifolius, Ocotea bullata (Lauraceae) and Olea capensis spp. marcocarpa (Oleaceae)), which is found in valleys and on the south-facing slopes of the adjacent river catchments A variety of fynbos types occupy

\footnotetext{
${ }^{1}$ Other affiliation: Department of Environmental and Geographical Science, University of Cape Town, Rondebosch, South Africa

${ }^{2}$ Other affiliation: School of Geographic Sciences, East China Normal University, Shanghai, China; and College of Geography and Environmental Sciences, Zhejiang Normal University, China
} 


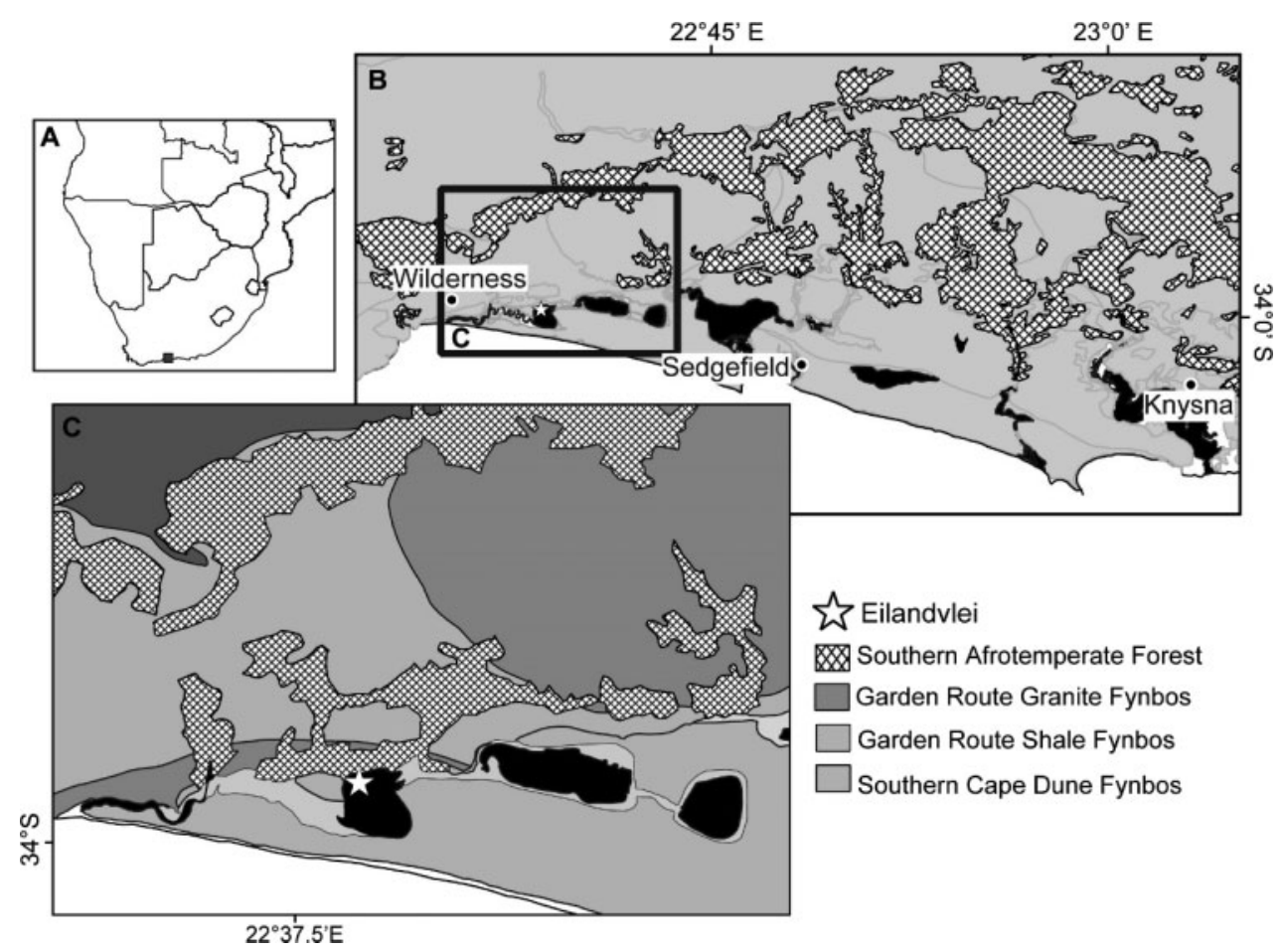

Figure 1. (A) Map of Africa showing the location of the southern Cape coast. (B) A section of the southern Cape coast between the towns of Wilderness and Knysna indicating the location of Eilandvlei and the current extent of Afrotemperate forest in the region. (C) The location of sediment core EV11 and the contemporary distribution of the dominant vegetation types (Mucina and Rutherford 2006).

this region including Garden Route Shale Fynbos (distinguished by ericaceous and tall dense proteoid fynbos), Knysna Sand Fynbos (primarily Erica curvifolia, Metalasia densa (Asteraceae) and Passerina rigida) and Southern Cape Dune Fynbos (predominantly Olea exasperata, Phylica litoralis and a variety of Searsia species).

\subsection{SEDIMENT DESCRIPTION AND METHODS}

The EV11 core $\left(33^{\circ} 59^{\prime} 23.10^{\prime \prime} \mathrm{S}, 22^{\circ} 38^{\prime} 17.60^{\prime \prime} \mathrm{E}, 0 \mathrm{~m}\right.$ asl $)$ was retrieved using a portable vibracorer mounted on a floating platform. The final core length measured $\sim 1.54 \mathrm{~m}$. The mean grain size varies from 5.89 to $7.27 \phi$ with the standard deviation ranging from 1.85 to 2.33 indicating very poorly sorted, fine to coarse silts to be the principal sedimentological components of EV11.

Forty-seven subsamples, with a minimum weight of $2 \mathrm{~g}$, were analysed using standard palynological methods as per Faegri and Iversen (1989) and Moore et al. (1991) with adaptations for dense media separation (Nakagawa et al. 1998). Pollen grains were examined and counted using a Zeiss Axiostar Plus microscope. Identifications were achieved through comparison with reference material from the Environmental and Geographical Science department at the University of Cape Town and published material (Van Zinderen Bakker 1953, Van Zinderen Bakker and Coetzee 1959, Welman and Kuhn 1970, Scott 1982). Charcoal particles were counted together with 
the pollen grains using the particle count method (Tinner and Hu 2003). Fragments were classified according to size: $10-50 \mu \mathrm{m}$ and 50-100 $\mu \mathrm{m}$. The exotic marker Lycopodium was added during preparation to enable pollen and charcoal concentrations to be calculated (one tablet per sample; Lund University, Batch \# 483216, $18583 \pm 1708$ spores per tablet). Two samples were omitted due to insufficient pollen concentrations; depths 80 and $138 \mathrm{~cm}$. A total pollen sum of 500 grains, or three slides, was achieved for each sample. On considering the results, it was deemed appropriate to remove the local aquatic components and Amaranthaceae from the pollen sum. Pollen assemblage zones were determined by the use of cluster analysis by the application of CONISS (Constrained Incremental Sum of Squares) (Grimm 1987) - all identified taxa were included in this analysis.

\subsection{DATING}

Seven organic sediment samples were selected for AMS- $-{ }^{14} \mathrm{C}$ dating at Beta Analytic Inc (USA) (Table 2). The two top samples returned pre-bomb ages and were calibrated using CALIBomb

Table 1. Sediment description for core EV11.

\begin{tabular}{llll}
\hline $\begin{array}{l}\text { Depth from } \\
\text { surface }(\mathrm{cm})\end{array}$ & Sediment colour & $\begin{array}{l}\text { Munsell } \\
\text { notation }\end{array}$ & Sedimentology \\
\hline $0-16$ & very dark brown & 10 YR 4/2 & sandy clay \\
$16-36$ & dark greyish brown & 10 YR 3/2 & fine sand and silt \\
$36-82$ & very dark greyish brown & $2.5 \mathrm{Y} \mathrm{4/1}$ & fine sand and silt \\
$82-115$ & very dark grey & $2.5 \mathrm{Y} \mathrm{3/1}$ & fine silt, sand and clay \\
$115-154$ & very dark grey & $2.5 \mathrm{Y} \mathrm{3/1}$ & fine silt, sand and clay \\
\hline
\end{tabular}

Table 2. Radiocarbon and calibration details for EV11. Samples were data at Beta Analytic Inc. as indicated by the laboratory identification.

\begin{tabular}{|c|c|c|c|c|c|c|c|}
\hline $\begin{array}{l}\text { Lab ID } \\
\text { (Beta-) }\end{array}$ & $\begin{array}{l}\text { Depth } \\
\text { (cm) }\end{array}$ & $\begin{array}{l}{ }^{14} \mathrm{C} \text { age } \\
\text { (yr BP) }\end{array}$ & $\begin{array}{l}1 \sigma \\
\text { error }\end{array}$ & $\begin{array}{l}\text { Calib. } \\
\text { data set }\end{array}$ & $\Delta \mathrm{R}$ & $\begin{array}{l}2 \sigma \text { cal age } \\
\text { range } \\
(\text { cal BP })\end{array}$ & $\begin{array}{l}\text { Median } \\
\text { probability } \\
\text { (cal BP) }\end{array}$ \\
\hline EV11-1 & 0 & - & - & CALIBomb & - & - & -58.7 \\
\hline EV11-2 & 20 & - & - & CALIBomb & - & - & -4.8 \\
\hline EV11-3 & 40 & 470 & 30 & Marine13 & $252 \pm 64$ & $\begin{array}{l}340-352 \\
451-526\end{array}$ & 497 \\
\hline EV11-7 & 78 & 1290 & 30 & Marine13 & $252 \pm 64$ & $\begin{array}{l}1072-1192 \\
1206-1268\end{array}$ & 1171 \\
\hline EV11-4 & 102 & 2140 & 30 & Marine13 & $252 \pm 64$ & $\begin{array}{l}2002-2154 \\
2276-2287\end{array}$ & 2074 \\
\hline EV11-6 & 134 & 3300 & 30 & Marine13 & $252 \pm 64$ & $3397-3568$ & 3485 \\
\hline EV11-5 & 151 & 3620 & 30 & Marine13 & $252 \pm 64$ & $\begin{array}{l}3726-3751 \\
3791-3794 \\
3820-3980\end{array}$ & 3880 \\
\hline
\end{tabular}




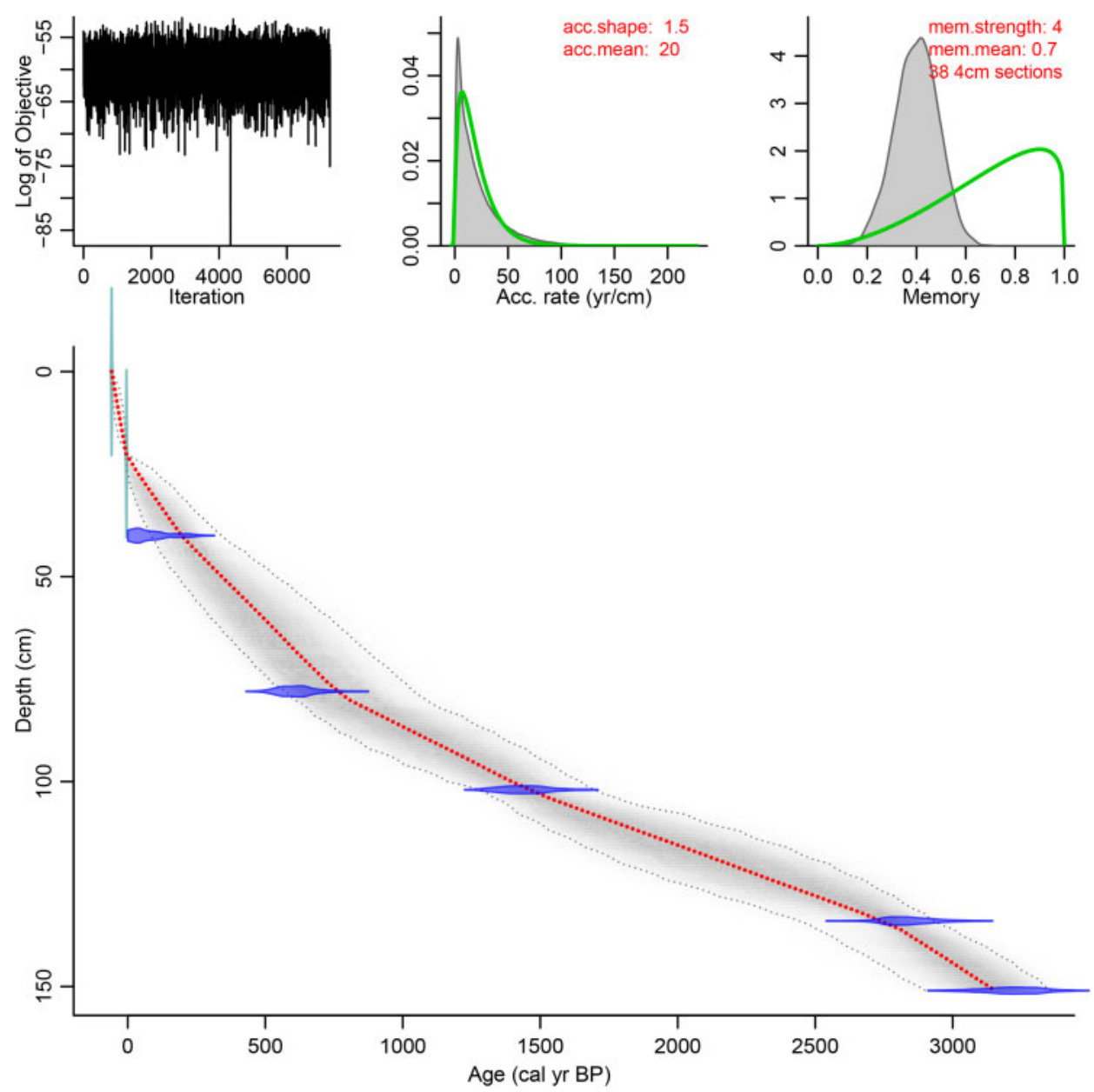

Figure 2. The EV11 age-depth model. The $2 \sigma$ probability distribution of calibrated ${ }^{14} \mathrm{C}$ ages is presented in blue and the $95 \%$ confidence intervals are represented by the grey dotted line. The red line represents the best model according to the weighted mean age at each depth.

(Reimer et al. 2004). The remainder of the samples were calibrated with the Marine13 data set (Reimer et al. 2013) with a marine reservoir correction of $\Delta \mathrm{R}=252 \pm 64$ (Wündsch et al. 2016). The age-depth model (Figure 2) was developed with the R software package Bacon (v2.2) (Blaauw and Christen 2011).

\subsection{INTERPRETATION}

In total 65 taxa were identified. Pollen concentrations range from $6.26 \times 10^{3}$ grains $\cdot \mathrm{g}^{-1}$ near the base, to a maximum of $7.86 \times 10^{4}$ grains $\cdot \mathrm{g}^{-1}$ around the top of the assemblage, with an average of $2.72 \times 10^{4}$ grains $\cdot \mathrm{g}^{-1}$. The EV11 record extends from c. 3100 cal yr BP to present. 
The sequence is divided into five pollen zones labelled EV11-A to E as set out below.

\subsubsection{EV11-A (3100 - 2560 cal yr BP; $148-130 \mathrm{~cm} ; 8$ samples): Drought resistant - Afrotemperate forest taxa}

Elevated levels of drought resistant taxa (i.e. Aizoaceae, Pentzia-type and Euphorbia) are seen at the onset of record, with Euphorbia present throughout the zone. Stoebe-type percentages are similarly increased, though decline towards the top of zone. Ericaceae pollen percentages are somewhat higher, at an average of $5.1 \%$, in comparison to the zone above. Afrotemperate forest pollen (primarily Podocarpus/Afrocarpus) increase after $3000 \mathrm{cal}$ yr BP, from 7.9 to $12.7 \%$ at the top of the zone, with coastal thicket taxa (mostly Olea, Searsia and Euclea) well represented from the start of the record with values ranging from 12 to $19.8 \%$. The maximum number of large charcoal fragments $(50-100 \mu \mathrm{m})$, interpreted to be indicative of a large more local fire event, is noted at $2600 \mathrm{cal}$ yr BP. These trends suggest that moisture availability was fairly limited, but rainfall was likely gradually increasing over this period.

\subsubsection{EV11-B (2560 - 1560 cal yr BP; $128-106$ cm; 11 samples): Amaranthaceae}

Zone EV11-B is strongly dominated by the halophytic taxon Amaranthaceae with a distinct increase after $2600 \mathrm{cal}$ yr BP from 13.7 to $43.7 \%$. This could be representative of expanding salt marsh vegetation in response to lower sea levels. Fluctuating forest pollen percentages are noted from around 2400 until 1600 cal yr BP with maximum charcoal concentrations concomitant with the increased presence of Podocarpus/Afrocarpus at $2260 \mathrm{cal} \mathrm{yr}$ BP. Restionaceae is more prominent in this zone than elsewhere in the record.

\subsubsection{EV11-C (1560 - 670 cal yr BP; $104-76 \mathrm{~cm}$; 9 samples): Afrotemperate Forest}

Podocarpus/Afrocarpus pollen is more prominent in comparison to the zones below, likely representing a phase of increasing forest expansion. At the same time, fynbos (largely Ericaceae) show a moderate decline towards the top of the zone, from 32.9 to $24.5 \%$, indicating a shift towards a more mesic environment with reduced rainfall seasonality.

\subsubsection{EV11-D (670 - 70 cal yr BP/AD 1880; 70-30.5 cm; 13 samples): Afrotemperate forest - drought resistant taxa; Stoebe-type}

Forest development continues until $360 \mathrm{cal} \mathrm{yr} \mathrm{BP,} \mathrm{with} \mathrm{a} \mathrm{sudden} \mathrm{break} \mathrm{in} \mathrm{this} \mathrm{trend} \mathrm{around} 620 \mathrm{cal}$ yr BP. After 360 cal yr BP a rather abrupt decline in Afrotemperate forest pollen is noted - from 17.5 to $10.7 \%$ in a period of $c$. 50 years. Drought resistant taxa (mostly Euphorbia) become more prevalent from this point with a rapid increase in Stoebe-type pollen (13.6\%) around $130 \mathrm{cal}$ yr BP. These vegetation responses are likely a result of the cooler and drier conditions experienced in the region during the latter part of the so called Little Ice Age $(650-100$ cal yr BP) (Jones et al. 2001; Matthews and Briffa 2005).

\subsubsection{EV11-E (70 to -30 cal yr BP/AD 1880 to $1980 ; 26-12 \mathrm{~cm} ; 4$ samples): Pinus}

The most recent part of the record is characterised by the appearance of Pinus pollen $c$. AD 1910 marking the onset of the anthropogenic influence in the region.

These results are broadly consistent with the pollen record from EV13. For a fuller discussion on the palaeoclimatic inferences please see (Quick et al. 2018). 


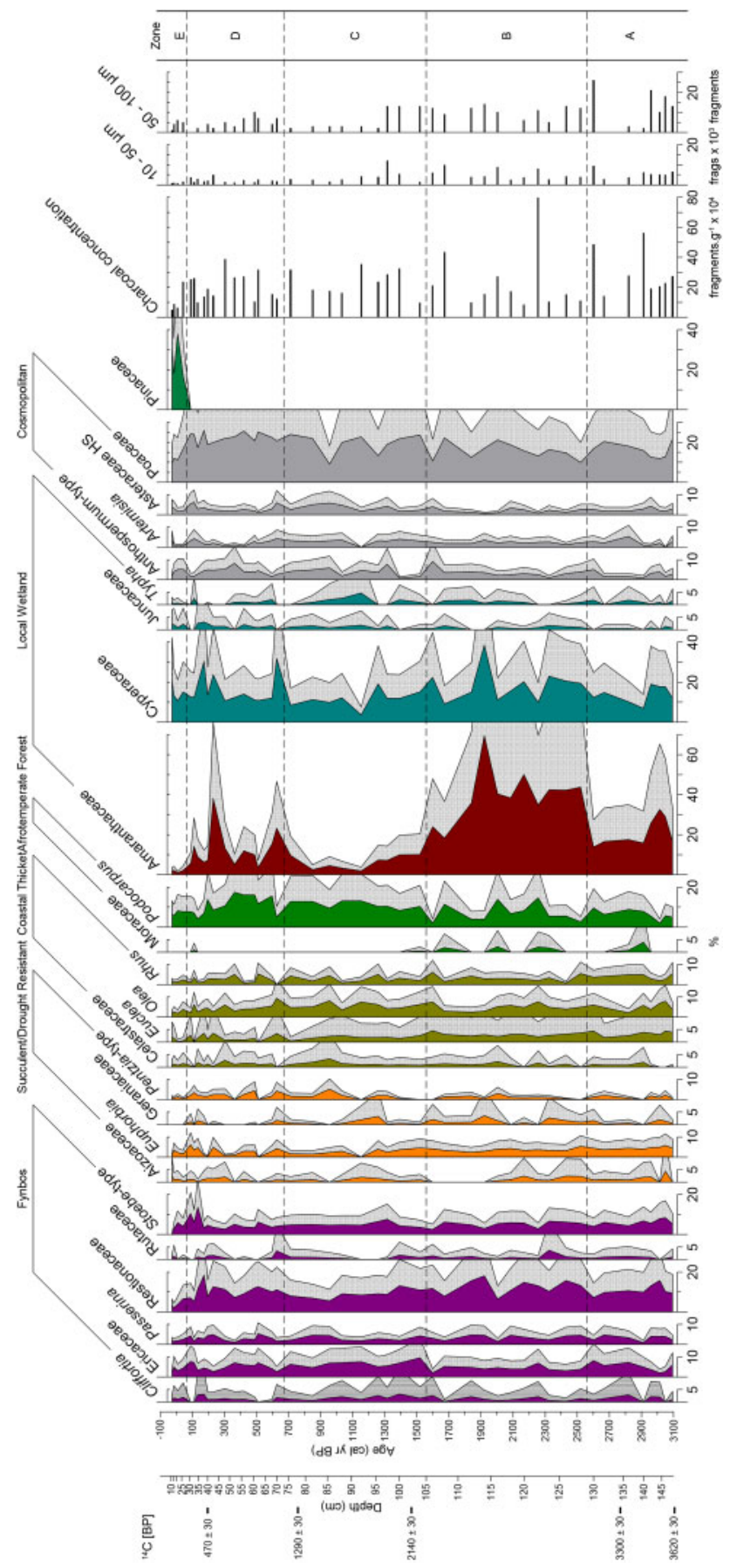

Figure 3. Relative pollen percentage diagram for EV11 organised according to ecological affinity, with charcoal concentrations and charcoal fragment counts. Pollen taxa occurring at less than $5 \%$ are not shown. Exaggeration curves are $2 \mathrm{x}$ for the taxa presented here. Charcoal and pollen concentrations were calculated in the same manner using Lycopodium counts. 


\section{DATA AVALIABILITY}

The pollen and microcharcoal data presented here is available at: http://apps.neotomadb.org/Explorer/?datasetid=48877

\section{ACKNOWLEDGEMENTS}

This study was funded in part by the German Federal Ministry of Education and Research (BMBF). The investigations were conducted as part of a pilot study for the collaborative project 'Regional Archives for Integrated Investigations' (RAiN), which is embedded in the international research programme SPACES (Science Partnership for the Assessment of Complex Earth System Processes). We also thank the anonymous reviewer and William Gosling for their constructive comments.

\section{REFERENCES}

Blaauw, M. and Christen, J.A., 2011, Flexible paleoclimate age-depth models using an autoregressive gamma process. Bayesian Analysis, 6(3), pp.457-474, 10.1214/ba/1339616472.

Faegri, K. and Iversen, J., 1989. Textbook of Pollen Analysis, Chichester: John Wiley \& Sons Ltd.

Grimm, E.C., 1987, CONISS: A Fortran 77 program for stratigraphically constrained cluster analysis by the method of incremental sum of squares. Computers \& Geosciences, 13, pp.1335, 10.1016/0098-3004(87)90022-7.

Jones, P.D., Osborn, T.J. and Briffa, K.R., 2001, The evolution of climate over the last millennium. Science, 292(5517), pp.662-667, 10.1126/science.1059126.

Matthews, J.A. and Briffa, K.R., 2005, The' Little Ice Age': Re-Evaluation of an Evolving Concept. Geografiska Annaler. Series A, Physical Geography, 87(1), pp.17-36.

Moore, P.D., Webb, J.A. and Collinson, M.E., 1991, Pollen Analysis 2nd edition, (Oxford: Blackwell Scientific Publications).

Mucina, L. and Rutherford, M.C., 2006, The Vegetation of South Africa, Lesotho and Swaziland, (Pretoria: South African National Biodiveristy Institute, Sterlitzia).

Nakagawa, T., Brugiapaglia, E., Digerfeldt, G., Reille, M., De Beaulieu, J.L. and Yasuda, Y., 1998, Dense media separation as a more efficient pollen extraction method for use with organic sediment/deposit samples: comparison with the conventional method. Boreas, 27, pp.15-24, 10.1111/j.1502-3885.1998.tb00864.X.

Quick, L.J., Chase, B.M., Wundsch, M., Kirsten, K.L., Chevalier, M., Mäusbacher, R., Meadows, M.E. and Haberzettl, T., 2018, A high-resolution record of Holocene climate and vegetation dynamics from the southern Cape coast of South Africa: pollen and microcharcoal evidence from Eilandvlei. Journal of Quaternary Science, 33(5), pp.487-500, 10.1002/jqs.3028.

Reimer, P.J., Bard, E., Bayliss, A., Beck, J.W., Blackwell, P.G., Ramsey, C.B., Buck, C.E., Cheng, H., Edwards, R.L., Friedrich, M., Grootes, P.M., Guilderson, T.P., Haflidason, H., Hajdas, I., Hatté, C., Heaton, T.J., Hoffmann, D.L., Hogg, A.G., Hughen, K.A., Kaiser, K.F., Kromer, B., Manning, S.W., Niu, M., Reimer, R.W., Richards, D.A., Scott, E.M., Southon, J.R., Staff, R.A., Turney, C.S.M. and van der Plicht, J., 2013, IntCal13 and Marine13 Radiocarbon Age Calibration Curves 0-50,000 Years cal BP. Radiocarbon, 55(04), pp.18691887, 10.2458/azu_js_rc.55.16947.

Reimer, P.J., Brown, T.A. and Reimer, R.W., 2004, Discussion: Reporting and Calibration of Post-Bomb ${ }^{14}$ C Data. Radiocarbon, 46(3), pp.1299-1304, 10.1017/S0033822200033154.

Scott, L., 1982, Late Quaternary fossil pollen grains from the Transvaal, South Africa. Review of Palaeobotany and Palynology, 36(3-4), pp.241-278, 10.1016/0034-6667(82)90022-7. 
Tinner, W. and Hu, F.S., 2003, Size parameters, size-class distribution and area-number relationship of microscopic charcoal: Relevance for fire reconstruction. The Holocene, 13(4), pp.499-505, 10.1191/0959683603hl615rp.

Welman, W.G. and Kuhn, L., 1970, South African Pollen Grains and Spores, Volume VI, (Amsterdam-Cape Town: AA Balkema).

Wündsch, M., Haberzettl, T., Meadows, M.E., Kirsten, K.L., Kasper, T., Baade, J., Daut, G., Stoner, J.S. and Mäusbacher, R., 2016, The impact of changing reservoir effects on the ${ }^{14} \mathrm{C}$ chronology of a Holocene sediment record from South Africa. Quaternary Geochronology, 36, pp.148-160, 10.1016/j.quageo.2016.08.011.

Van Zinderen Bakker, E.M., 1953, South African Pollen Grains and Spores, Volume I, (Cape Town: AA Balkema).

Van Zinderen Bakker, E.M. and Coetzee, J.A., 1959, South African Pollen Grains and Spores, Volume III, (Cape Town: AA Balkema). 